\title{
Openness of the insurance market for foreign entities: methodology and experience of Ukraine
}

\section{Tatyana Vieriezubova}

Ph.D., Associate Professor, Department of Tax and Taxation, Belarusian State Economic University, the Republic of Belarus

\section{Valentina Levchenko}

Ph.D., Executive Director, All-Ukrainian professional public organization "Union of Auditors of Ukraine", Ukraine

\begin{abstract}
The article is devoted to the development of methodical tools for determining the level of openness of the insurance market in Ukraine. The proposed level of openness of the insurance market of Ukraine should be considered as an opportunity (potential) for domestic insurers to interact effectively with foreign investors and financial intermediaries. It has been established that the mathematical tool for realizing the task should be a gravity modeling, which, taking into account the inflow and outflow of the characteristics of the openness of the insurance market of Ukraine, allows us to determine the degree of its remoteness from the insurance markets of Europe and the World. It is proved that the openness of the insurance market of Ukraine serves not only as an indicator of the level of readiness of the interaction of domestic financial intermediaries with foreign entities, but also fully characterizes the infrastructural level of the Ukrainian insurance market.
\end{abstract}

Keywords: insurance market, level of openness, gravity modeling, insurance company, inflow, outflow.

JEL Classification: G22.

DOI: $10.21272 /$ fmir.1(2).87-95.2017.

(C) The Authors, 2017. This article is published with open access at ARMG Publishing.

\section{Inroduction}

Liberalization of financial relations has different aspects of influence, it can lead to intensification of domestic financial intermediaries, increase their capitalization and activate infrastructure transformations, or, conversely, cause loss of national companies, create a monopoly in the market and minimize the possibilities of state regulatory bodies.

Certainly, each of these scenarios of development depends on the characteristics of the national insurance market and the stage of its development. In the realities of the functioning of the Ukrainian insurance market, globalization processes serve as a catalyst for the development of financial intermediaries. However, on the example of the Ukrainian banking financial services market we can state that foreign capital and foreign technologies are actively entering the market only during its period of higher-than-market-growth and favorable economic as well as political situation in the country. Subsequently, if the market does not grow and does not develop, foreign capital withdraws from the market, that was observed in 2014-2015 in the banking sector, after its active expansion by foreign banks in 2005-2007.

At the same time, it should be noted that the insurance market of Ukraine differs markedly from its analogues in other countries and from the banking sector. The low levels of capitalization, poor extension of financial services among the population, incapable state regulator cause not only the underdeveloped infrastructure of this market, but also its low involvement in the integration processes. Proceeding from the above mentioned, the topical becomes the study of the level of openness of the insurance market of Ukraine, as an indicator of the level of readiness of the cooperation of domestic financial intermediaries with foreign economic entities and the characteristics of certain aspects of the development of this market. Only with a high level of openness the national insurance market is fully capable to participate in international processes of formation, distribution and redistribution of capital. 


\section{Literature review}

For many years foreign and Ukrainian scholars have paid considerable attention to the problems of assessing the impact of the openness of any market on economic growth in the country and the development of tools for its quantitative measurement. Thus, foreign scholars who were focused on the study of the openness of the financial market are Zhang, Z. [11], Xiangsheng Dou [10], Edwards S. [2], Quinn D., Inclan C. [6]. The authors whose works relate to the definition of the relationship between openness and the growth of the economy are Arena M. [1], Haiss P., Sumegi K. [3], Kjosevski J. [4], Skipper H. D. [8]. Among the domestic scientists who studied the problem of openness of the insurance market and investigated its impact on the economic growth of the country as a whole there are Bazylevych V. D. [12], Hamankova O.O., Osadets S.S., Artiukh T.M. [16], Shirinian L.V. [17]. In its turn, the works of Shaffle A. [7], Tindergen J. [9], Kuzmenko O.V. [14] and others are devoted to the problems of using the tools of gravitational modeling to solve economic problems. The aim of the study is the quantitative determination of the level of openness of the Ukrainian insurance market and the study of its dynamic changes, as well as the prospects of its growth.

\section{Main results of investigation}

Determining the key aspects of the formation of the scientific and methodical approach to assessing the level of openness of the insurance market of Ukraine, we note that in the first place it is necessary to choose a mathematical tool for its implementation. Proceeding from the fact that the category of openness is proposed to consider as an opportunity (potential) to interact effectively with foreign investors and financial intermediaries, then a gravitational modeling is chosen as a mathematical tool for the realization of this task. The reason for choosing this mathematical tool is the fact that the essence of gravitational modeling is adapted to social phenomena. In our study the force of attraction is proposed to be considered as a quantitative assessment of the real or potential opportunities for cooperation between actors in different markets. The quantitative assessment of gravitational attraction is identified as the level of openness of the investigated market, that is, if the indicator of gravitational attraction increases, it can be stated that the level of openness between different insurance markets is increasing. In our case, based on the measurement of force of attraction the conclusion about the level of openness of the investigated market is drawn.

The implementation of the stages of the scientific and methodical approach to determining the level of openness of the insurance market in Ukraine has the following sequence:

1. The choice of indicators describing the incoming information flow of the gravitational modeling process.

2. Formation of an integral indicator of the characteristics of the incoming information flow for assessing the openness of the insurance market in Ukraine.

3. Identification of the factors of the information outflow of the gravitational modeling process.

4. Calculation of the integral indicator of the characteristics of the information outflow for assessing the openness of the insurance market in Ukraine.

5. Assessing the distance of the Ukrainian insurance market from other markets.

6. Determination of the level of openness of the insurance market of Ukraine on the basis of the law of gravity.

Having established the algorithm for implementing the scientific and methodical approach to assessing the level of openness of the insurance market of Ukraine, we will consider each stage in more detail. Thus, the indicators of the characteristics of the incoming information flow of the level of openness of the insurance market of Ukraine (construction of the layout of Table 1 is conditioned by the need to introduce symbols for further mathematical formalization of the necessary patterns ) proposed to choose are the following: global competitiveness index, corruption perception index, index of ease of doing business, incoming reinsurance. These indicators describe how favorable the business environment in Ukraine is for insurance activities. The three suggested indexes describe the conditions that international financial intermediaries will face in their activities in Ukraine. Incoming reinsurance characterizes the existing situation with the level of interaction between domestic and foreign insurance markets. 
Table 1. Layout of the incoming information flow characteristics to determine the level of openness of the insurance market in Ukraine

\begin{tabular}{|c|c|c|c|c|c|c|}
\hline Indicator & Direction & $1^{\text {st }}$ year & $\ldots$ & $\begin{array}{l}\text { i-th } \\
\text { year }\end{array}$ & $\cdots$ & $\begin{array}{l}\text { n-th } \\
\text { year }\end{array}$ \\
\hline A & $\mathrm{B}$ & 1 & 2 & 3 & 4 & 5 \\
\hline Global competitiveness index, units & stimulator & $a_{11}$ & $\ldots$ & $a_{1 i}$ & $\ldots$ & $a_{\ln }$ \\
\hline Corruption perception index, units & de-stimulator & $a_{21}$ & $\ldots$ & $a_{2 i}$ & $\ldots$ & $a_{2 n}$ \\
\hline Index of ease of doing business, units & stimulator & $a_{31}$ & $\ldots$ & $a_{3 i}$ & $\ldots$ & $a_{3 n}$ \\
\hline $\begin{array}{l}\text { Incoming reinsurance (received insurance premiums from } \\
\text { reinsurers-non-residents), UAH million }\end{array}$ & stimulator & $a_{41}$ & $\ldots$ & $a_{4 i}$ & $\cdots$ & $a_{4 n}$ \\
\hline
\end{tabular}

Practical data for a comprehensive analysis of the dynamics of global competitiveness index, corruption perception index and index of ease of doing business, as well as variations of incoming reinsurance are presented in Table 2.

Table 2. Indicators of the incoming information flow for determining the level of openness of the insurance market of Ukraine for 2006-2015

\begin{tabular}{|c|c|c|c|c|c|c|c|c|c|c|}
\hline \multirow{2}{*}{ Indicator } & \multicolumn{10}{|c|}{ Year } \\
\hline & 2006 & 2007 & 2008 & 2009 & 2010 & 2011 & 2012 & 2013 & 2014 & 2015 \\
\hline $\mathrm{A}$ & 1 & 2 & 3 & 4 & 5 & 6 & 7 & 8 & 9 & 10 \\
\hline Global competitiveness index & 4.11 & 3.96 & 4.00 & 3.56 & 3.31 & 3.39 & 3.52 & 3.46 & 3.54 & 3.18 \\
\hline Corruption perception ndex & 2.6 & 2.8 & 2.5 & 2.2 & 2.4 & 2.5 & 2.6 & 2.5 & 2.6 & 2.7 \\
\hline Index of ease of doing business & 124 & 138 & 144 & 146 & 142 & 145 & 152 & 137 & 112 & 96 \\
\hline Incoming reinsurance, UAH mln. & 21.5 & 112.2 & 317.5 & 242.1 & 192.3 & 429.1 & 279.8 & 324 & 12.9 & 38.1 \\
\hline
\end{tabular}

Source: $[8,5,11]$.

In order to implement the gravitational modeling the incoming information flow must be presented as a single indicator. That is, the formation of methodical principles for constructing the integral indicator, which describes the current situation in the domestic insurance market from the point of view of the possibility of operation of foreign financial intermediaries in it, becomes relevant. However, it should be noted that the essential disadvantage of the information provided is the impossibility of comparing the indicators with each other, since they reflect different aspects of functioning of economic entities, have their own peculiarities and development trends, as well as different units of measurement. That is why it is suggested to get the data of Table 2 to the comparable form (Table 3) by application of natural normalization for the stimulator indicators (formula 1) and normalization of Savage for the de-stimulator indicators (formula 2):

$$
\begin{aligned}
& \tilde{a}_{j i}=\left[\begin{array}{l}
0, a_{j i}=\min _{i}\left\{a_{j i}\right\} \\
\frac{a_{j i}-\min _{i}\left\{a_{j i}\right\}}{\max _{i}\left\{a_{j i}\right\}-\min _{i}\left\{a_{j i}\right\}}, \min _{i}\left\{a_{j i}\right\}<a_{j i}<\max _{i}\left\{a_{j i}\right\}, \\
1, a_{j i}=\max _{i}\left\{a_{j i}\right\}
\end{array}\right. \\
& \tilde{a}_{j i}=\left[\begin{array}{l}
0, a_{j i}=\min _{i}\left\{a_{j i}\right\} \\
\frac{\max _{i}\left\{a_{j i}\right\}-a_{j i}}{\max _{i}\left\{a_{j i}\right\}-\min _{i}\left\{a_{j i}\right\}}, \min _{i}\left\{a_{j i}\right\}<a_{j i}<\max _{i}\left\{a_{j i}\right\} \\
1, a_{j i}=\max _{i}\left\{a_{j i}\right\}
\end{array}\right.
\end{aligned}
$$

where $\tilde{a}_{j i}$ - normalized value of $j$-th indicator of the characteristics of the level of openness of the insurance market based on the incoming information flow for the $i$-th time interval; $a_{j i}$-initial value of the $j$-th indicator of the characteristics of the level of openness of the insurance market based on the incoming information flow for the $i$-th time interval; $\min _{i}\left\{a_{j i}\right\}$ - minimum value of the $j$-th indicator of the characteristics of the level of openness of the insurance market based on the incoming information flow over the entire period of the study; 
$\max _{i}\left\{a_{j i}\right\}$ - maximum value of the $j$-th indicator of the characteristics of the level of openness of the insurance market based on the incoming information flow over the entire period of the study.

Table 3. Normalized values of indicators of the incoming information flow for determining the level of openness of the insurance market of Ukraine for 2006-2015

\begin{tabular}{|l|c|c|c|c|c|c|c|c|c|c|}
\hline \multirow{2}{*}{ Indicator } & \multicolumn{10}{c|}{ Year } \\
\cline { 2 - 13 } & 2006 & 2007 & 2008 & 2009 & 2010 & 2011 & 2012 & 2013 & 2014 & 2015 \\
\hline A & 1 & 2 & 3 & 4 & 5 & 6 & 7 & 8 & 9 & 10 \\
\hline Global competitiveness index & 1.00 & 0.84 & 0.89 & 0.41 & 0.14 & 0.23 & 0.36 & 0.30 & 0.39 & 0.00 \\
\hline Corruption perception ndex & 0.67 & 1.00 & 0.50 & 0.00 & 0.33 & 0.50 & 0.67 & 0.50 & 0.67 & 0.83 \\
\hline Index of ease of doing business & 0.50 & 0.25 & 0.14 & 0.11 & 0.18 & 0.13 & 0.00 & 0.27 & 0.71 & 1.00 \\
\hline Incoming reinsurance & 0.02 & 0.24 & 0.73 & 0.55 & 0.43 & 1.00 & 0.64 & 0.75 & 0.00 & 0.06 \\
\hline
\end{tabular}

The summing up of the aforementioned data to the generalized indicator of quantitative assessment of the level of openness of the insurance market based on the incoming information flow provides scaling down the indicators within the lines and graphs. This process is based on the calculation of the average values of the incoming data and takes the form of the following formula:

$$
I H V h_{i}=\frac{\sum_{j=1}^{4} \sum_{i=1}^{n} \tilde{a}_{j i}}{4 n}
$$

where $I H V h_{i}$ - integral estimation of the characteristics of the level of openness of the insurance market based on the incoming information flow; $n$ - total number of study periods.

The dynamics of the integral estimation of the level of openness of the insurance market based on the incoming information flow will be presented graphically (Figure 1).

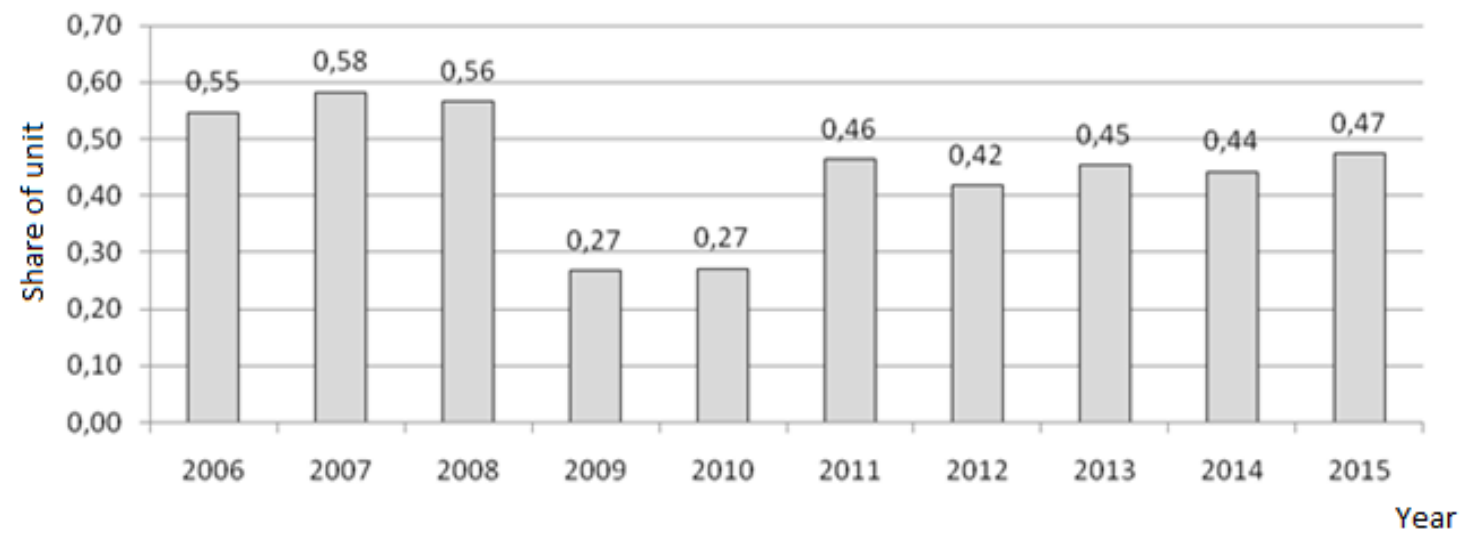

Figure 1. Integral estimation of the level of openness of the insurance market based on the incoming information flow

Based on the analysis of the data shown in Figure 1, it should be noted that during the investigated period the integral estimation characterizing the conditions and level of cooperation of domestic financial intermediaries with foreign ones had a slight variation. Thus, during 2006-2015 the performance indicator was in the range of 0.42-0.55 units, the exception was only in the period from 2009 to 2010, when the deterioration of the values of all indicators of the incoming information flow was due to the consequences of the financial crisis. Over the past five years the integral indicator of the assessment of the openness of the insurance market based on the incoming information flow was at the level of 0.42-0.47 units, which demonstrates the insufficient use of existing opportunities in the modern international financial system.

Similarly to the above-described essence and the mechanism for assessing the level of openness of the insurance market based on the incoming information flow at the fourth stage of the proposed scientific and methodological approach, we will consider the sequence of calculating the level of openness of the insurance market based on the information outflow. First, we will make a selection of relevant indicators and collection of statistics concerning their quantitative characteristics. It should be noted that the group of indicators of the informational outflow of openness of the insurance market should describe the result that is observed in the 
market due to its openness. Proceeding from this, it is proposed to select two indicators of the characteristics of information outflow of the level of openness of the insurance market of Ukraine: outgoing reinsurance and the share of foreign capital in the authorized capital of insurers. For the purpose of further mathematical formalization of the process of gravitational modeling of the level of openness of the insurance market Table. 4 is made.

Table 4. Characteristics of the information outflow determining the level of openness of the insurance market of Ukraine

\begin{tabular}{|c|c|c|c|c|c|c|}
\hline Indicator & Direction & $1^{\text {st }}$ year & $\ldots$ & i-th year & $\ldots$ & n-th year \\
\hline A & $\mathrm{B}$ & 1 & 2 & 2 & 4 & 5 \\
\hline Payments compensated for reinsurers-non-residents, UAH mln. & Stimulator & $p_{11}$ & $\ldots$ & $p_{1 i}$ & $\ldots$ & $p_{1 n}$ \\
\hline The share of foreign capital in the authorized capital of insurers, \% & Nominator & $p_{21}$ & $\ldots$ & $p_{2 i}$ & $\ldots$ & $p_{2 n}$ \\
\hline
\end{tabular}

Realizing the reason for selecting the two indicators specified in column A of the Table 4, we note that payments compensated for reinsurers-non-residents, characterize the readiness of cooperation of international insurance companies with domestic financial intermediaries, as well as the level of trust of non-residents to the Ukrainian insurance market. Certainly, the greater the value of the outgoing reinsurance, the greater the level of openness of the domestic insurance market, as foreign companies actively cooperate with Ukrainian insurance companies. The share of foreign capital in the statutory capital of insurers shows the investment attractiveness of the insurance market, the efficiency of doing business in Ukraine and the trust of foreign companies to the domestic insurance market. However, this indicator is not appropriate to consider as a stimulator, since the share of foreign capital in the authorized capital of insurers at the level of more than 50\% indicates: high probability of monopolization of the insurance market by foreign companies; diminishing the ability of state regulators to defend their national interests; the loss of Ukraine's insurance market of its national identity. Thus, the value of the given indicator at the level of 40-50\% indicates the high openness of the insurance market, its national affiliation and relative independence.

Characteristics of the information outflow determining the level of openness of the insurance market of Ukraine for 2006-2015 are presented in Table 5.

Table 5. Characteristics of the information outflow determining the level of openness of the insurance market of Ukraine

\begin{tabular}{|c|c|c|c|c|c|c|c|c|c|c|}
\hline \multirow{2}{*}{ Indicator } & \multicolumn{9}{|c|}{ Year } \\
\cline { 2 - 12 } & 2006 & 2007 & 2008 & 2009 & 2010 & 2011 & 2012 & 2013 & 2014 & 2015 \\
\hline A & 1 & 2 & 3 & 4 & 5 & 6 & 7 & 8 & 9 & 10 \\
\hline $\begin{array}{l}\text { Payments compensated for rein- } \\
\text { surers-non-residents, UAH mln. }\end{array}$ & 13.5 & 504.1 & 1055.6 & 1050.4 & 1837.1 & 578 & 15.9 & 27.4 & 9.9 & 12.9 \\
\hline $\begin{array}{l}\text { The share of foreign capital in the } \\
\text { authorized capital of insurers, \% }\end{array}$ & 13 & 20.7 & 25.5 & 26.9 & 28.3 & 29.8 & 31.4 & 33.1 & 34.9 & 36.7 \\
\hline
\end{tabular}

Source: $[8,5,11]$.

Successive transition from the outgoing data shown in Table 5 to the compared to each other indicators of quantitative assessment of the level of openness of the insurance market (based on the information outflow) will be carried out by natural normalization of the indicator-stimulator (formula 4) and using formula (5) for indicator-nominator (Table 6):

$$
\tilde{p}_{j i}=\left[\begin{array}{l}
0, p_{j i}=\min _{i}\left\{p_{j i}\right\} \\
\frac{p_{j i}-\min _{i}\left\{p_{j i}\right\}}{\max _{i}\left\{p_{j i}\right\}-\min _{i}\left\{p_{j i}\right\}}, \min _{i}\left\{p_{j i}\right\}<p_{j i}<\max _{i}\left\{p_{j i}\right\}, \\
1, p_{j i}=\max _{i}\left\{p_{j i}\right\}
\end{array}\right.
$$




$$
\tilde{p}_{j i}=\left[\begin{array}{l}
1-\frac{\left|p_{j i}-p_{\text {jnorm }}\right|}{\max \left\{\left(\max _{i}\left\{p_{j i}\right\}-p_{\text {jnorm }}\right) ;\left(p_{\text {jnorm }}-\min _{i}\left\{p_{j i}\right\}\right)\right\}} \\
\frac{1}{n-1} \sum_{j=2}^{n}\left(1-\frac{\left|p_{j i}-p_{\text {jnorm }}\right|}{\max \left\{\left(\max _{i}\left\{p_{j i}\right\}-p_{\text {jnorm }}\right) ;\left(p_{\text {jnorm }}-\min _{i}\left\{p_{j i}\right\}\right)\right\}}\right) \\
\text { if } p_{j i}=\max _{i}\left\{p_{j i}\right\}, p_{j i}=\min _{i}\left\{p_{j i}\right\}
\end{array}\right.
$$

where $\tilde{p}_{j i}$ - normalized value of $j$-th indicator of the level of openness of the insurance market based on the information outflow for the $i$-th time interval; $p_{j i}$ - value of $j$-th indicator of the level of openness of the insurance market based on the information outflow for the $i$-th time interval; $\min _{i}\left\{p_{j i}\right\}$ - minimum value of the $j$-th indicator of the level of openness of the insurance market based on the information outflow over the entire period of the study; $\max _{i}\left\{p_{j i}\right\}$ - maximum value of the $j$-th indicator of the level of openness of the insurance market based on the information outflow over the entire period of the study; $p_{\text {jnorm }}$ - boundary (nominal) value of the $j$-th indicator of the level of openness of the insurance market based on the information outflow over the entire period of the study (the share of foreign capital in the authorized capital of insurers is 50\%).

Thus, the results of comparative data of the information outflow determining the level of openness of the insurance market of Ukraine are presented in Table 6.

Table 6. Normalized indicators of the information outflow determining the level of openness of the insurance market of Ukraine

\begin{tabular}{|c|c|c|c|c|c|c|c|c|c|c|}
\hline \multirow{2}{*}{ Indicator } & \multicolumn{10}{|c|}{ Year } \\
\hline & 2006 & 2007 & 2008 & 2009 & 2010 & 2011 & 2012 & 2013 & 2014 & 2015 \\
\hline $\mathrm{A}$ & 1 & 2 & 3 & 4 & 5 & 6 & 7 & 8 & 9 & 10 \\
\hline $\begin{array}{l}\text { Payments compensated for reinsur- } \\
\text { ers-non-residents }\end{array}$ & 0.00 & 0.27 & 0.57 & 0.57 & 1.00 & 0.31 & 0.00 & 0.01 & 0.00 & 0.00 \\
\hline $\begin{array}{l}\text { The share of foreign capital in the au- } \\
\text { thorized capital of insurers }\end{array}$ & 0.45 & 0.21 & 0.34 & 0.37 & 0.41 & 0.45 & 0.50 & 0.54 & 0.59 & 0.64 \\
\hline
\end{tabular}

Similar to the incoming information flow, it is necessary to operate with integral indicators for the implementation of the gravitational modeling. Thus, the generalization of the represented statistical data and their quantitative description with one indicator is proposed to make based on formula (6):

$$
\text { IHVih }_{i}=\frac{\sum_{j=1}^{2} \sum_{i=1}^{n} \tilde{p}_{j i}}{2 n},
$$

where $\mathrm{HVih}_{i}$ - integral estimation of the level of openness of the insurance market based on the information outflow for the $i$-th time interval; $n$ - total number of study periods.

The dynamics of the integral estimation of the level of openness of the insurance market based on the information outflow will be presented graphically (Figure 2).

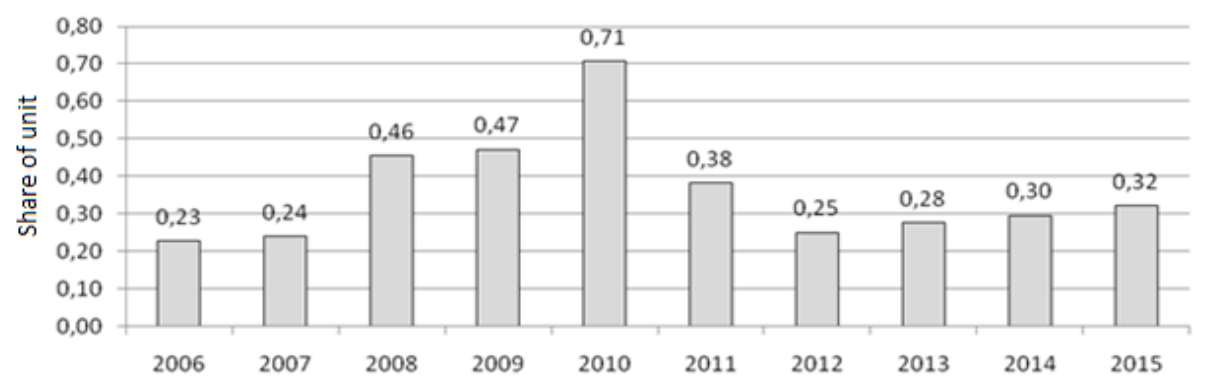

Figure 2. Integral estimation of the level of openness of the insurance market based on the information outflow 
Exploring the tendency pictured in Figure 2 we should note the following: if the abnormal integral indicator of the level of openness of the insurance market based on the information outflow is not taken into account, then during the whole period the performance indicator did not rise more than 0.47 of the share of unit. This testifies to the insignificant openness of the Ukrainian insurance market. In its turn, the abnormal integral indicator of the level of openness of the insurance market based on the information outflow is caused by significant negative consequences of the implementation of insurance risks in 2010, which were under the proportional responsibility of the Ukrainian reinsurers too. Thus, analyzing the dynamics of two integral indicators (incoming and outgoing information flows), it is fair to note that the domestic companies do not use the potential opportunities for expanding cooperation with foreign insurers.

The next, fifth stage of the scientific and methodical approach to determining the level of openness of the Ukrainian insurance market is the direct application of gravitational modeling. Proceeding from the fact that the essence of gravitational modeling is to evaluate the force of attraction of several elements, the calculation of the size of the gap between the insurance market of Ukraine and foreign insurance markets is relevant. In the conditions of adaptation of gravitational modeling to the economic situation, the indicator characterizing the size of the gap is proposed to choose the index of economic freedom. This is due to the fact that this index characterizes all aspects of business organization in Ukraine, its profitability and features of conduct, as well as the attractiveness of cooperation between international companies with Ukrainian counterparts and the state activity in the field of entrepreneurship. Proceeding from the fact that the index of economic freedom includes the following indexes as freedom of business, freedom of trade, tax freedom, public spending, monetary freedom, freedom of investment, financial freedom, protection of property rights, freedom from corruption, freedom of labor relations, it fully corresponds to the logic of the construction of the chosen model. Indicators of indexes of economic freedom, breakdown of their actual and reference values (the difference between this index and 100\%) are given in Table 7.

Table 7. Dynamics of the size of the gap between the index of economic freedom and the reference value for the period from 2006 to 2015

\begin{tabular}{|c|c|c|c|c|c|c|c|c|c|c|}
\hline \multirow{2}{*}{ Indicator } & \multicolumn{10}{|c|}{ Year } \\
\hline & 2006 & 2007 & 2008 & 2009 & 2010 & 2011 & 2012 & 2013 & 2014 & 2015 \\
\hline $\begin{array}{l}\text { Index of economic } \\
\text { freedom, } \%\end{array}$ & 54.4 & 51.5 & 51 & 48.8 & 46.4 & 45.8 & 46.1 & 46.3 & 49.3 & 46.9 \\
\hline $\begin{array}{l}\text { The gap between the } \\
\text { index of economic } \\
\text { freedom and the ref- } \\
\text { erence value of } \\
100 \% \text {, the share of } \\
\text { unit }\end{array}$ & 0.456 & 0.485 & 0.49 & 0.512 & 0.536 & 0.542 & 0.539 & 0.537 & 0.507 & 0.531 \\
\hline
\end{tabular}

Let's summarize the results of the calculations carried out at 1-5 stages of the scientific and methodical approach to determine the level of openness of the insurance market of Ukraine in Table 8, which will provide an opportunity to form the information base for determining the desired level of openness of the insurance market in Ukraine.

Table 8. Information base for determining the level of openness of the insurance market of Ukraine for the period from 2006 to 2015, units

\begin{tabular}{|l|c|c|c|c|c|c|c|c|c|c|}
\hline \multicolumn{1}{|c|}{ Indicators } & \multicolumn{7}{c|}{ Year } & \multicolumn{7}{c|}{} \\
\cline { 2 - 10 } & 2006 & 2007 & 2008 & 2009 & 2010 & 2011 & 2012 & 2013 & 2014 & 2015 \\
\hline $\begin{array}{l}\text { Integral estimation of the level } \\
\text { of openness of the insurance } \\
\text { market based on the incoming } \\
\text { information flow }\end{array}$ & 0.5468 & 0.5824 & 0.5650 & 0.2672 & 0.2716 & 0.4640 & 0.4180 & 0.4535 & 0.4422 & 0.4735 \\
\hline $\begin{array}{l}\text { Integral estimation of the level } \\
\text { of openness of the insurance } \\
\text { market based on the infor- } \\
\text { mation outflow }\end{array}$ & 0.2266 & 0.2393 & 0.4551 & 0.4721 & 0.7068 & 0.3827 & 0.2505 & 0.2763 & 0.2955 & 0.3215 \\
\hline $\begin{array}{l}\text { The gap between the index of } \\
\text { economic freedom and the ref- } \\
\text { erence value }\end{array}$ & 0.4560 & 0.4850 & 0.4900 & 0.5120 & 0.5360 & 0.5420 & 0.5390 & 0.5370 & 0.5070 & 0.5310 \\
\hline
\end{tabular}


Given in Table 8 characteristics form the basis for the application of gravitational modeling by adapting the law of gravity to the analogy of force of attraction in social phenomena. in particular. determining the level of openness of the insurance market in Ukraine. the sixth stage of the scientific and methodological approach.

The essence of the law of gravity regarding the formal presentation of factors for assessing the openness of the insurance market is that the level of openness of the insurance market is interpreted as a value directly proportional to the estimates of its level of openness based on the incoming and outgoing information flows and inversely proportional to the square of the value of the gap between the index of economic freedom and the reference value:

$$
R V F R_{i}=\frac{I H V h_{i} \cdot I H V i h_{i}}{I E S_{i}^{2}}
$$

where $R V F R_{i}$ - quantitative assessment of the level of openness of the insurance market for the $i$-th time interval; $I H V h_{i}$ - integral estimation of the level of openness of the insurance market based on the incoming information flow for the $i$-th time interval; $I H V i h_{i}$ - integral rating characteristics of the level of openness of the insurance market based on the information outflow for the $i$-th time interval; $I E S_{i}$ - value of the gap between the index of economic freedom and the reference value for the $i$-th time interval.

Application of the formula (7) allows obtaining such a time series of the level of openness of the insurance market of Ukraine for the period from 2006 to 2015 (Table 9).

Table 9. Dynamics of the level of openness of the insurance market of Ukraine for the period from 2006 to 2015

\begin{tabular}{|l|c|c|c|c|c|c|c|c|c|c|}
\hline \multirow{2}{*}{ Indicator } & \multicolumn{9}{|c|}{ Year } \\
\cline { 2 - 10 } & 2006 & 2007 & 2008 & 2009 & 2010 & 2011 & 2012 & 2013 & 2014 & 2015 \\
\hline $\begin{array}{l}\text { Level of } \\
\text { openness of the } \\
\text { insurance } \\
\text { market of } \\
\text { Ukraine }\end{array}$ & 0.5960 & 0.5924 & $1.0708^{*}$ & 0.4811 & 0.6681 & 0.6046 & 0.3604 & 0.4346 & 0.5083 & 0.5399 \\
\hline
\end{tabular}

Notes: *abnormal value indicating crisis phenomena.

Thus. it should be noted that during 2006-2015 the level of openness of the insurance market of Ukraine varied unevenly. First of all, it should be noted that the calculated value of the level of openness of the insurance market of Ukraine in 2008 at the level of 1.0708 units indicates the adequacy of the model, because it is an abnormal level of openness, which is inappropriate to take into account. It is associated with the financial crisis this year. Regarding the indicators of openness of the insurance market of Ukraine in other years it should be noted that on average they are at the level of 0.5 units to 0.6 units. The only exceptions are the years after financial instability, namely: 2009, 2011-2013. This tendency allows us to conclude that the insurance market of Ukraine is sufficiently open, but the level of this openness (this indicator is at the level of not more than 60\%) testifies to the impossibility of further changes in the investigated market. That is, despite the creation of certain conditions in the insurance market of Ukraine for cooperation with foreign companies, there were no further steps to increase the openness of both financial intermediaries and the state.

\section{Conclusions and directions for further research}

Consequently. establishing on the basis of gravitational modeling the level of openness of the insurance market of Ukraine actualizes the formation of tools for its increase and effective use. So, the priorities in the current realities of functioning of the insurance market are: the introduction of Solvency II provisions in domestic legislation. changes in the model of state regulation of the insurance market, creation of effective selfregulatory organizations, reduction and complete elimination of bureaucratic procedures in the insurance market of Ukraine, development of world-wide types of insurance, increasing the financial literacy of the population. At the same time, it should be noted that the gradual increase in the level of openness of the insurance market should be accompanied by its effective use by market participants. Thus, increasing the openness of the market leads to the entrance of large international companies, which can be competed with only if there is 
sufficient capitalization. The business model of the activity of domestic companies in the process of cooperation with foreign partners must be changed, gaining a clear structure and high efficiency.

\section{References}

1. Arena, M. (2008). Does insurance market promote Economic Growth? A cross-country Study for Industrialized and developing countries. Journal of Risk Insurance, 75 (4), 921-946.

2. Bazylevych, V.D. (2008). Strakhuvania: pidruchnyk [Insurance: textbook]. Kyiv : Znania [in Ukrainian], $1019 \mathrm{p}$.

3. Edwards, S. (1998). Openness. Productivity and Growth: What Do We Really Know? Economic Journal, 108 (March), 383-398.

4. Haiss, P., Sumegi. K. (2008). The relationship between insurance and economic growth in Europe: a theoretical and empirical analysis. Empirica, 35 (4), 405-431.

5. Informatsiia pro stan i rozvytok strakhovoho rynku Ukrainy za period 2005-2015 / Natsionalna Komisiia, scho zdiisniuie derzhavne rehuliuvania u sferi rynkiv finansovykh posluh [Information on the state and development of the insurance market of Ukraine for the period of 2005-2015 / National Commission which provides state regulation in the field of financial services markets] [Electronic resource]. Available at http://nfp.gov.ua/content/informaciya-pro-stan-i-rozvitok.html.

6. Kjosevski, J. (2011). Impact of Insurance on Economic Growth: the Case of Republic of Macedonia. European Journal of Business and Economics, 4, 34-39.

7. Kuzmenko, O.V. (2013). Doslidzhenia problem I vyznachenia rivnia vidkrytosti rynku perestrekhuvania na osnovi hravitatsiinoho modeliuvania [Investigation of problems and determining the level of openness of reinsurance market based on gravitational modeling]. Visnyk Ukrainskoi Akademii Bankivskoi Spravy, № 1, P. 125-134.

8. Non-bank financial institutions : Assessment of their impact on the stability of the stability of the financial system. Available at http://ec.europa.eu/economy_finance/publications/economic_paper/2012/pdf/ ecp472_en.pdf.

9. Osadets, S.S., Artiukh, T.M. Hamankova, O.O., at al. (2007). Strakhovi posluhy [Insurance services]. Kyiv: KNEU, 464 p.

10. Quinn, D., \& Inclan, C. (1997). The origins of financial openness: A study of current and capital account liberalization. American Journal of Political Science, 41(3), 771-813.

11. Richni zvity Natsionalnoi Komisii. scho zdiisniuie derzhavne rehuliuvania u sferi rynkiv finansovykh posluh za period 2012-2015 [Annual reports of the National Commission which provides state regulation in the field of financial services markets for the period of 2005-2015] [Electronic resource]. Availavle at http://nfp.gov.ua/content/rzviti-nackomfinposlug.html.

12. Shirinian, L.V. (2014). Finansove rehuliuvania strakhovoho rynku Ukrainy: problem teorii ta praktyky: monohrafiya [Financial regulation of the Ukrainian insurance market: problems of theory and practice: monograph. Kyiv: Publishing house "Tsentr uchbovoi literatury" [in Ukrainian], 458 p.

13. Shaffle, A. (1873). Das Gesellschaftliche System der Menschlichen Wirtschaft, 850 p.

14. Skipper, H. D., Kwon, W. J. (2007). Risk Management and Insurance: Perspectives in a Global Economy. Blackwell Publishing. Ltd., Oxford.

15. Tindergen, J. (1962). Shaping the World Economy: Suggestions for an International Economic Policy. New York. The Twentieth Century Fund, P. $34-58$.

16. Xiangsheng Dou (2016) Measure and Evaluation of Financial Openness in China. International Journal of Economics and Financial Issues, 6(3), 985-994.

17. Zhang, Z. (2008). A review of measurement method for financial openness. Economic Trends, 12(3), 117-120. 